\title{
Urban Wastewater Treatment by Adsorption of Organic Matters on Modified Bentonite by (Iron-Aluminum)
}

\author{
Meçabih Zohra1 ${ }^{*}$, Jérôme Rose ${ }^{2}$, Daniel Borschneck ${ }^{2}$ \\ ${ }^{1}$ Materials Catalysis Laboratory, Department of Chemistry, University of Sidi Bel-Abbes, Sidi Bel-Abbes, Algeria \\ ${ }^{2}$ Géoscience de l'Environnement UMR 6635, Cerege, Université Aix-Marseille, Europôle Méditerranéen de \\ I'Arbois III, BP 8013545 Aix en Provence cedex 4, France \\ Email: ${ }^{\text {zmecabih@gmail.com }}$
}

Received 15 June 2014; revised 12 July 2014; accepted 10 August 2014

Copyright (C) 2014 by authors and Scientific Research Publishing Inc.

This work is licensed under the Creative Commons Attribution International License (CC BY). http://creativecommons.org/licenses/by/4.0/

(c) (i) Open Access

\begin{abstract}
In this research, the natural bentonite clay (from Maghnia, western Algeria) was purified ( $\mathrm{Na}^{+-}$ montmorillonite, $\mathrm{CEC}=\mathbf{9 1} \mathrm{meq} / \mathbf{1 0 0} \mathrm{g}$ ), noted (puri.bent) and modified with mixed hydroxy-Fe-Al (FeAl-PILC). The purified bentonite clay and FeAl-PILC were heated at $383 \mathrm{~K}$ for $2 \mathrm{hr}$ and characterized by the chemical analyses data, XRD, and $\mathrm{N}_{2}$ adsorption to $77 \mathrm{~K}$ techniques. Puri.bent and FeAl-PILC were applied to fix the organic matter $(\mathrm{OM})$ present in urban wastewater from the city of Sidi Bel-Abbes (western Algeria). The adsorption of organic matter was followed by spectrophotometry at $470 \mathrm{~nm}$, and the adsorption data were a good fit with Freundlich isotherm for puri.bent but for FeA-IPILC, were well fit by Elovitch isotherm model. The maximum adsorption capacity $\left(q_{m}\right)$ was $571.6 \mathrm{mg} / \mathrm{g}$ for puri.bent and $1120.69 \mathrm{mg} / \mathrm{g}$ for FeAl-PLC. The degree of OM removal was $67 \%$ for puri.bent and $97 \%$ for FeAl-PILC. FeAl-PILC can be considered as a promising adsorbent for the removal of $\mathrm{OM}$ from wastewater.
\end{abstract}

\section{Keywords}

Adsorption, Urban Wastewater, Bentonite Clay, Isotherm Models

\section{Introduction}

In Algeria, recycled wastewater effluent was an important source of irrigation water, about 500 million $\mathrm{m}^{3}$ of wastewater effluent was produced per year [1]. Wastewater treatment plants (STEP) of Sidi Bel-Abbes city, lo-

${ }^{*}$ Corresponding author.

How to cite this paper: Zohra, M., Rose, J. and Borschneck, D. (2014) Urban Wastewater Treatment by Adsorption of Organic Matters on Modified Bentonite by (Iron-Aluminum). Journal of Encapsulation and Adsorption Sciences, 4, 71-79. http://dx.doi.org/10.4236/jeas.2014.43008 
cated on the Mekerra River (western Sidi Bel-Abbes) at the exit of the city have the capacity for treating $300,000 \mathrm{Eq} / \mathrm{H}$, purifying the liquid part of the sewage and attempt to remove most pollutants, excess nutrients and pathogens from wastewater [2]. Wastewater effluent treated discharged into river and the leftover solids and semi solids were filtered from wastewater making up the "sewage sludge some" [2] [3].

Wastewater effluent undergoes five major processes: primary treatment, secondary treatment, disinfection and finally sludge treatment, before the treated wastewater, disinfected and discharged into Mekerra River. However, treated wastewater contains higher concentrations of suspended and dissolved organic and inorganic matter was only minimally removed from the effluent [4] [5]. Adsorption on solid substrates, such as clay or activated carbon, was one of the methods, which have been used for removing OM from wastewater.

Bentonite clay which was available in large quantities can be used as an adsorbent particularly FeAl-PILC, for the removal of many aromatic organic pollutants from wastewater [6]-[10], heavy toxic metals [11] [12], and colors [13].

This study aimed the removal of the organics matters from urban wastewater treatment plant (STEP) from Sidi Bel-Abbes city by purified bentonite clay and FeAl-PILC.

\section{Materials and Methods}

\subsection{Purified Bentonite Clay}

The natural bentonite (from Maghnia, west Algeria) was fractionated by sedimentation to obtain the $<2 \mu \mathrm{m}$ montmorillonite rich faction. The purification was prepared in laboratory [2], the carbonates were removed by sodium acetate/chloridric acid, iron oxides by sodium thiosulfate/sodium chloridric and organic materials by hydrogen peroxide (30\% vol). To ensure complete transformation into the sodium from all samples, they were washed several times with $0.5 \mathrm{M} \mathrm{NaCl}$. The important physico-chemical properties reported in Table 1 with the $\mathrm{SiO}_{2} / \mathrm{Al}_{2} \mathrm{O}_{3}$ ratio equal 2.63 indicated that the major mineral was the montmorillonite.

\subsection{Preparation of Solution of Hydroxyl-(FeAl) Inter-Layered}

The pillaring solutions of hydroxy- $\mathrm{Al}$ and hydroxy-Fe were prepared separately according to the procedure previously reported in literature [14]. $0.207 \mathrm{M} \mathrm{AlCl}_{3}$ was hydrolysed with $0.207 \mathrm{M} \mathrm{NaOH}$ from in solutions, with $\mathrm{OH} / \mathrm{Al}$ ratio of 2.5 and a pH of $4.3-4.5$. The final concentration of the Al-solution was $0.09 \mathrm{M}$, the hydroxyl-Al solution was aged at room temperature during 6 days.

For hydroxyl-Fe solution, by slowly adding a $0.1 \mathrm{M}$ solution aqueous of $0.1 \mathrm{M} \mathrm{NaOH}$ to a solution of $0.1 \mathrm{M}$ $\mathrm{FeCl}_{3}$ to obtain final acidic ratios $\mathrm{OH} / \mathrm{Fe}^{3+}=2.5, \mathrm{pH}$ of the final solution $\left(\left[\mathrm{Fe}^{3+}\right]=0.045 \mathrm{M}\right)$ was close 1 , i.e. The resulting solution was aged for 30 days at room temperature.

\subsection{Modified Bentonite by Mixed Hydroxyl FeAl (FeAl-PILC)}

The mixing solution hydroxy-Fe and hydroxy-Al (50\% - 50\%, in \% atomic) was slowly added under vigorous

\begin{tabular}{|c|c|c|c|c|}
\hline \multicolumn{3}{|c|}{ Chemical Composition (\% mass) } & \multirow{2}{*}{\multicolumn{2}{|c|}{ Physical Characteristics }} \\
\hline Element & SEM & EDS & & \\
\hline $\mathrm{SiO}_{2}$ & 57.96 & 52.51 & Loss on ignition (\%) & 12.19 \\
\hline $\mathrm{Al}_{2} \mathrm{O}_{3}$ & 22.05 & 21.25 & Density & 1 \\
\hline $\mathrm{Fe}_{2} \mathrm{O}_{3}$ & 2.83 & 2.25 & Granulometry $(\mu \mathrm{m})$ & 2 to 1 \\
\hline $\mathrm{CaO}$ & 8.49 & 15.0 & Capacity swelling Cg & 8.27 \\
\hline $\mathrm{Cl}_{2} \mathrm{O}$ & 1.138 & 1.25 & $\mathrm{pH}$ for $10 \mathrm{~g} / \mathrm{L}$ & 10.7 \\
\hline $\mathrm{MgO}$ & 2.37 & 2.37 & Conductance $(\mu \mathrm{S})$ for $0.5 \mathrm{~g} / \mathrm{L}$ & 66.4 \\
\hline $\mathrm{Na}_{2} \mathrm{O}$ & 1.91 & 1.25 & CEC (meq/g) & 0.90 \\
\hline $\mathrm{K}_{2} \mathrm{O}$ & 2.84 & 1.25 & & \\
\hline $\mathrm{TiO}_{2}$ & 0.12 & 2.50 & & \\
\hline
\end{tabular}


stirring to purified bentonite clay taking $\mathrm{M}^{3+}\left(\mathrm{M}^{+3}=\mathrm{Fe}^{3+}, \mathrm{Al}^{3+}\right) /$ clay ratio equal 0.065 and allowed to age overnight. Then, the product was collected by filtration and washed with deionized doubly distilled water until free of chlorides, as indicated by the $\mathrm{AgNO}_{3}$ test. The solid was dried overnight at $110^{\circ} \mathrm{C}$, ground and sieved.

\subsection{Characterisation Studies}

The clay mineralogy were analyzed by, X-ray Diffraction (XRD), the solids were calcined at $110^{\circ} \mathrm{C}$ for overnight, and measured by Philips PW 1729 powder-diffractometer, with CoK $\alpha$ radiation at $35 \mathrm{Kv}, 30 \mathrm{~mA}$, passing a Fe filter. To precisely confirm the presence of the $\left(\begin{array}{llll}0 & 0 & 1\end{array}\right)$ reflection peak in each sample, the XRD patterns in the $2 \theta$ range $2^{\circ}-14^{\circ}$ were also taken at steps of $0.02^{\circ}$ with scanning rate $0.05^{\circ} / \mathrm{min}$. Specific surface areas-BET, was determined by adsorption of nitrogen at $77 \mathrm{~K}$, using a Micromeritics ASAP 2010 instrument. The samples were previously outgassed by treatment at $120^{\circ} \mathrm{C}$ for $2 \mathrm{~h}$, under flow of nitrogen. The FTIR spectra were obtained using a Mattson-1000 FTIR spectrometer. The samples were prepared by mixing $1 \mathrm{mg}$ of sample with $100 \mathrm{mg}$ of $\mathrm{KBr}$ from pellets.

\subsection{Adsorption Equilibrium Experiment}

An mass $m$ (g) of adsorbents was put into a $50 \mathrm{~mL}$ reactor, into which $\mathrm{OM}$ of urban wastewater with different initial diluted concentrations, ranging from 3.16, 1.92 , 3.72 and 4.53, for periods (03/06/2012, 08/09/2012, 13/04/2013, 19/12/2013), respectively, Table 2 were added to reach a final volume of $50 \mathrm{ml}$. These dilutions were such that the initial concentration of OM was $126.4 \mathrm{mg} / \mathrm{l}$ for four periods, or a dilution average of 3.33 times. At $\mathrm{T}=25^{\circ} \mathrm{C}$ and $\mathrm{P}=1 \mathrm{~atm}$ the suspension was stirred for $30 \mathrm{~min}$, time of adsorption equilibrium ( $\mathrm{Z}$. Meçabih et al., 2006). After, by decanting for $2 \mathrm{~h}$, two-thirds of the supernatant liquid was removed and filtrated through a membrane $(1.2 \mu \mathrm{m})$ fiber glass filter. The concentration of the organic matter $(\mathrm{OM})$ in $30 \mathrm{ml}$ the supernatant was titrated by $\mathrm{KMnO}_{4}, 10^{-3} \mathrm{M}$. This titration was followed by sepctrophotometric (Speckol 10) at 470 $\mathrm{nm}\left(\lambda_{\max }\right.$ of OM absorption) [2]. All experiments were carried out in triplicates (test $3 \times 4$ periods) and the average values were reported in Figure 1(a), Figure 1(b), show the variation of the optical density of MO as a function of solution volume $\mathrm{KMnO}_{4} 10^{-3} \mathrm{M}$.

\section{Results and Discussion}

\subsection{Characterisation of Bentonite Clay and FeAl-PILC}

\subsubsection{XRD Analysis}

The basal spacing $d_{001}$ of two samples after calcinations at $383 \mathrm{~K}$, and the specific surface areas were presented in Table 3. As seen in Figure 2, the $\mathrm{d}_{001}$ position of FeAl-PILC was $14.50 \AA$ in comparison to $\mathrm{Na}^{+}$-montmorillonite which was $12.79 \AA$. The increase in basal spacing was due to pillaring [15]. The increase of the interlayer distance $\left(\mathrm{d}_{001}\right)$ after pillaring with hydroxyl FeAl-PILC was typical [10].

Table 2. Urban wastewater characteristics of Sidi Bel-Abbes city samples.

\begin{tabular}{ccccc}
\hline & \multicolumn{4}{c}{ Period } \\
\cline { 2 - 5 } Characteristic & 1: removal of & 2: removal of & 3: removal of & 4: removal of \\
\cline { 2 - 5 } & $03 / 06 / 2012$ & $08 / 09 / 2012$ & $13 / 04 / 2013$ & $19 / 12 / 2013$ \\
\hline MES (mg/L) & 675 & 417 & 798 & 939 \\
MO (mg/L) & 398.9 & 243.1 & 469.8 & 572.8 \\
DCO (mg. $\left.\mathrm{O}_{2} / \mathrm{L}\right)$ & 338 & 320 & 410 & 998.65 \\
DBO $_{5}\left(\mathrm{mg} \cdot \mathrm{O}_{2} / \mathrm{L}\right)$ & 179.25 & 160.6 & 210.87 & 530 \\
Nitrogenize $(\mathrm{mg} / \mathrm{L})$ & 76.2 & 32.96 & 54.12 & 83 \\
Nitrate-nitrite $(\mathrm{mg} / \mathrm{L})$ & $13-0.08$ & $15-0.11$ & $7-1.43$ & $12-0.35$ \\
Phosphate total $(\mathrm{mg} / \mathrm{L})$ & 19.66 & 25.80 & 42.15 & 47.09 \\
Temperature $\left({ }^{\circ} \mathrm{C}\right)$ & 25 & 25 & 26 & 25 \\
PH & 7 & 7 & 7.5 & 7.5 \\
\hline
\end{tabular}


Table 3. Basal spacing $\left(\mathrm{d}_{001}\right)$ and surface area of $\mathrm{Na}^{+}$-montmorillonite clay and FeAl-PILC.

\begin{tabular}{cccc}
\hline Samples & $2 \theta$ & $\mathrm{d}_{001}$ & SBET m $/ \mathrm{g}$ \\
\hline Puri.bent & 8.13 & 12.79 & 100.2 \\
FeAl-PILC & 10.34 & 15.57 & 277.16 \\
\hline
\end{tabular}

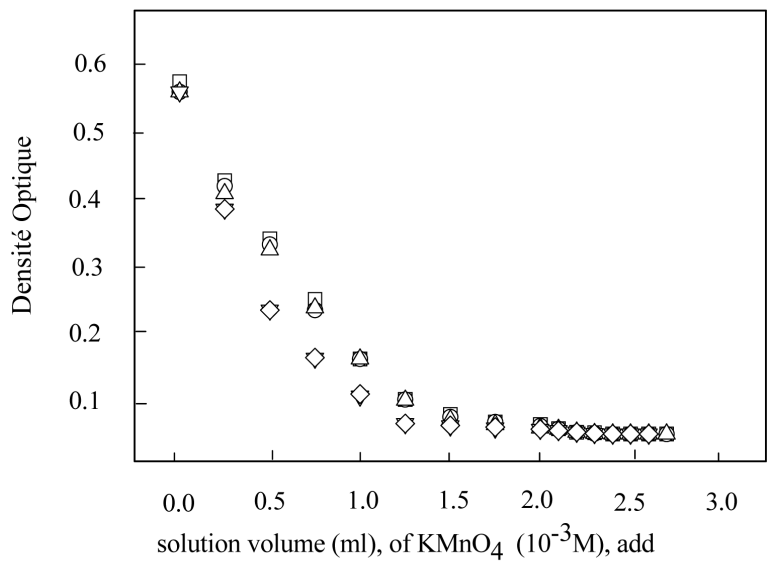

(a)

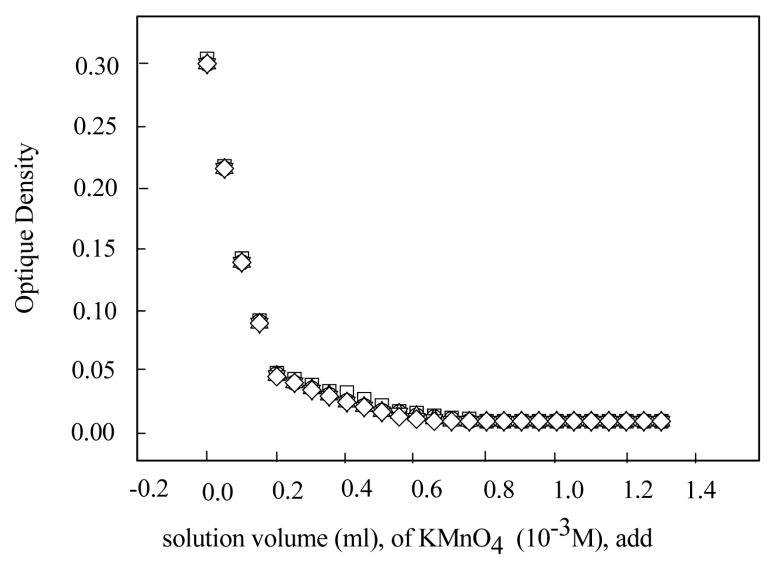

(b)

Figure 1. Absorbance variation (DO, $\lambda_{\max }=470 \mathrm{~nm}$ ) by solution volume, $\mathrm{KMnO}_{4}$ of: (a) Purified bentonite; (b) FeAl-PILC. $\square 10 \mathrm{mg}, \mathrm{O} 15 \mathrm{mg}, \Delta 20 \mathrm{mg}, \nabla 25 \mathrm{mg}, \diamond 30 \mathrm{mg}$.

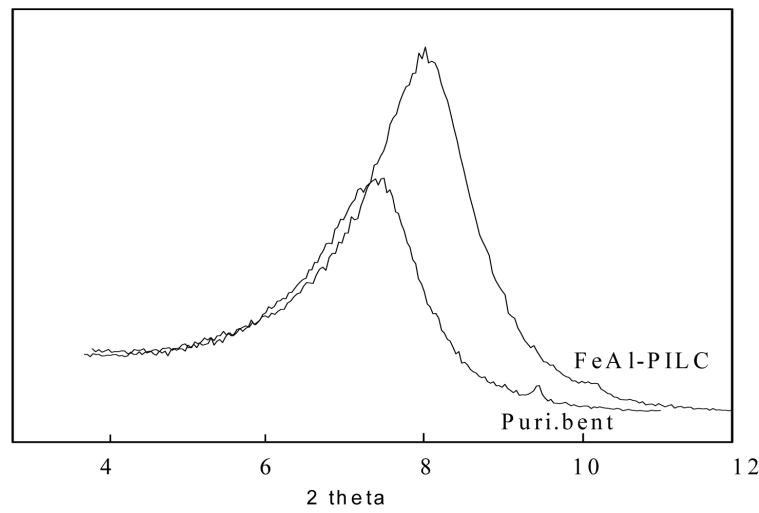

Figure 2. Basal spacing $\left(\mathrm{d}_{001}\right)$ of: (a) Purified bentonite; (b) FeAl-PILC at $383 \mathrm{~K}$. 


\subsubsection{BET Analysis}

The specific surface area, calculated from the $\mathrm{N}_{2}$ adsorption isotherms by the use of the Brunauer-Emmett-Teller (BET) equation, increased from $100.20 \mathrm{~m}^{2} \cdot \mathrm{g}^{-1}$ for puri.bent to $277.16 \mathrm{~m}^{2} \cdot \mathrm{g}^{-1}$ for FeAl-PILC Table 3. This increase after pillaring with FeAl-PILC, suggest also the increasing of the micropores [7].

\subsubsection{FTIR Analysis}

The FTIR spectra of purified bentonite (puri.bent) and modified clay FeAl-PILC samples were presented in Figure 3. The region of interest for determining structural composition was the frequency region between (1400 400) $\mathrm{cm}^{-1}$ which was characteristic of metal bonded silica [16] [17]. The broad absorption bands observed at $3446-3628 \mathrm{~cm}^{-1}$ represent the fundamental stretching vibrations of different -OH groups present in $\mathrm{Mg}-\mathrm{OH}-\mathrm{Al}$ $\left(3640 \mathrm{~cm}^{-1}\right)$, Al-OH-Al $\left(3620 \mathrm{~cm}^{-1}\right)$ and Fe-OH-Al $\left(885 \mathrm{~cm}^{-1}\right)$ units in the octahedral layer [17]. The most intensive band between $115-1020 \mathrm{~cm}^{-1}$ was related to antisymmetric stretching of the $\equiv \mathrm{Si}-\mathrm{O}-\mathrm{Si} \equiv$ bridge. The deformation mode was placed at $798 \mathrm{~cm}^{-1}$. The dolomite and quartz were identified by infrared spectroscopy as the main admixtures of clay raw material that was used as the source of montmorillonite. For montmorillonite this band ought to be evident at $1100 \mathrm{~cm}^{-1}$ according to Besson et al., 1987 [17]. The bands at 525, 620 and 917 $\mathrm{cm}^{-1}$ were assigned to Al-O-Si deformation, Si-O stretching, and Al-Al-OH deformation, respectively [16].

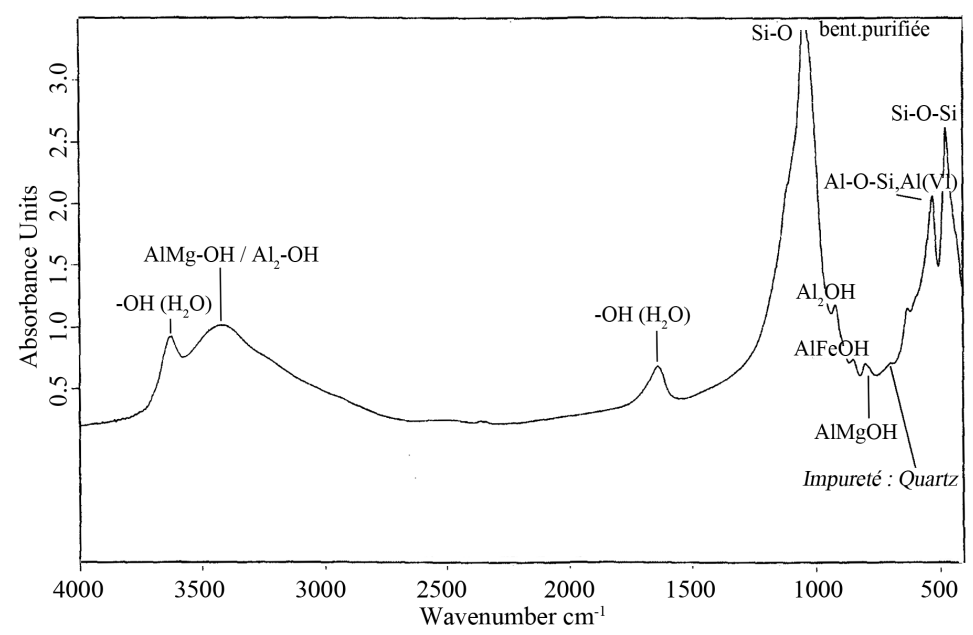

(a)

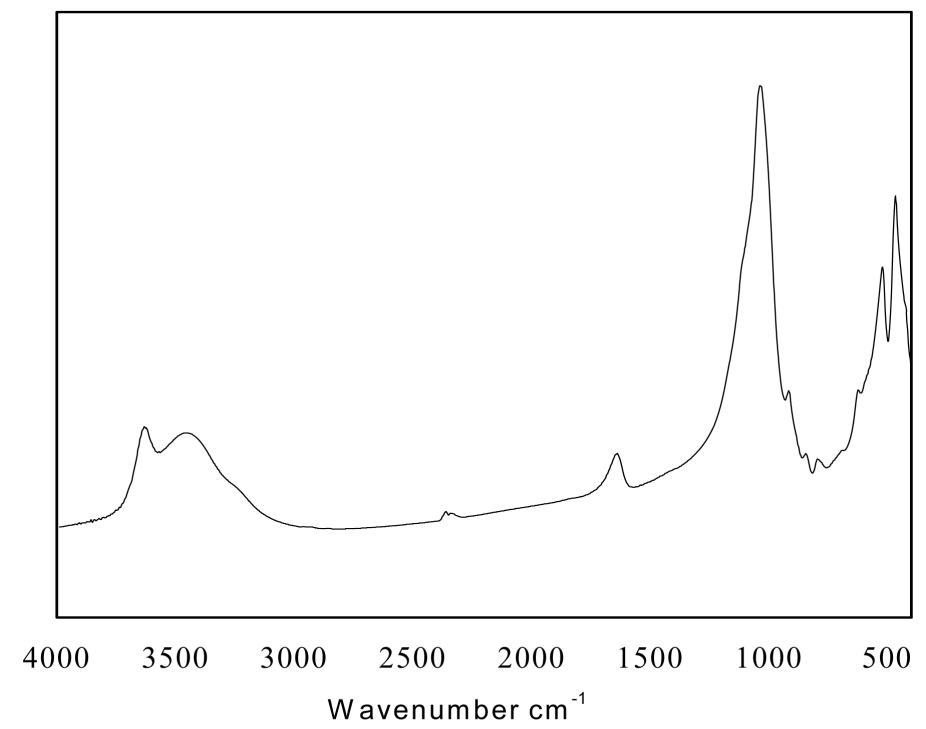

(b)

Figure 3. FT-IR spectra of: (a) Purified bentonite; (b) FeAl-PILC. 
These bands slightly shift to high wavenumber in the FT-IR spectra of (Fe-Al)-pillared bentonite at 627.96, 790.22 and $919.76 \mathrm{~cm}^{-1}$ respectively. The bands at $1036.51 \mathrm{~cm}^{-1}$ assigns to Si-O-Si stretching vibrations and band at $472.96 \mathrm{~cm}^{-1}$ assigns to the Si-O bending and $\mathrm{M}-\mathrm{O}$ stretching vibrations. These bands slightly shift to high wavenumber in IR spectra of Fe-Al pillared bentonite, which can be indirect evidence of the incorporation of $\mathrm{Fe}^{3+}$ into $\mathrm{Al}$-polycation, because the $\mathrm{Fe}-\mathrm{O}$ bond is longer than the $\mathrm{Al}-\mathrm{O}$ bond, so that the substitution of ions $\mathrm{Al}^{3+}$ by $\mathrm{Fe}^{3+}$ should be accompanied by a general shift to high wavenumber. Bands Si-O-Si, Si-O, and M-O were the most sensitive to these substitutions.

\subsection{Adsorption of Organic Matters from Urban Wastewater}

Table 2 illustrates the average values of the various parameters determined $\left(\mathrm{T}=22^{\circ} \mathrm{C} \pm 2^{\circ} \mathrm{C}\right)$ on the sample of urban wastewater. The concentration of $\mathrm{OM}$ was determined by calcination at $\left(625^{\circ} \mathrm{C} \pm 5^{\circ} \mathrm{C}\right)$, for periods $(1-4)$, 59.1, 58.3, 58.9, respectively with $61.0 \%$ of suspended solids (TS). In the period 4 (Table 2), the wastewater treatment plant (STEP) of Sidi Bel-Abbes city's, received the effluent flood and wineries waste very charged in organic matters OM. The values of the chemical oxygen demand (COD) indicated that the urban wastewater of Sidi Bel-Abbes city's, industrial quality.

The $\mathrm{BOD}_{5} / \mathrm{COD}$, around 0.52 indicates that the organic matters in the sample of urban wastewater can be biodegradable. Than more, $\mathrm{pH}$ around 7 was favourable for biological treatment, and the effluent of urban wastewater as for irrigation were feasible.

\subsection{Isotherm Models}

All isotherms were obtained at $\mathrm{pH} 7$ with initial OM concentrations $126.4 \mathrm{mg} / \mathrm{l}$ with different masses of clay ranging from 10 - $30 \mathrm{mg}$. The experimental data were fitted to Freundlich and Elovitch models using Equations (1) and (2), respectively. The parameters of the Freundlich and Elovitch models and correlation coefficient $\left(R^{2}\right)$ values for each clay type were presented in Table 4 . The data were adequately fitted by the two models which were consistent with reported results [2]. However, the Langmuir equation was not obeyed by OM adsorption data for both puri.bent and FeAl-PILC.

$$
\begin{aligned}
& q=\frac{x}{m}=K_{F} \times C^{\frac{1}{n}} \\
& \frac{q}{q_{m}}=K_{E} \times \exp \frac{q}{q_{m}}
\end{aligned}
$$

where $x$ and $m$ (g) were masses of adsorbed and adsorbent respectively, $C$ was the equilibrium concentration of the adsorbent $\left(\mathrm{mg} \cdot \mathrm{L}^{-1}\right) \cdot q\left(\mathrm{mg} \cdot \mathrm{g}^{-1}\right)$ and $q_{m}\left(\mathrm{mg} \cdot \mathrm{g}^{-1}\right)$ were capacity adsorption and maximum capacity adsorption respectively which were related to $\theta$ : recovery rate adsorption sites Equation (3). $K_{F}$ and $n$ were Freundlich constants; and $K_{E}$ was Elovich constant $\left(\mathrm{L} \cdot \mathrm{g}^{-1}\right)$. $n$ was related to energy of adsorption $Q_{0}$ Equation (4) constant of digital distribution energy of sorptive sites, $R$ universal gas constant and $T$ absolute temperature.

$$
\begin{gathered}
\theta=\frac{q}{q_{m}} \\
n=\frac{Q_{0}}{R T}
\end{gathered}
$$

\begin{tabular}{|c|c|c|c|c|c|c|}
\hline \multirow{2}{*}{ Samples } & \multicolumn{3}{|c|}{ Freundlich } & \multicolumn{3}{|c|}{ Elovitch } \\
\hline & $n$ & $K_{F}(\mathrm{~L} \cdot \mathrm{g} / \mathrm{L})$ & $R^{2}$ & $K_{E}(\mathrm{~L} \cdot \mathrm{g} / \mathrm{L})$ & $q_{m}(\mathrm{mg} \mathrm{OM} / \mathrm{g})$ & $R^{2}$ \\
\hline Puri.bent & 1.09 & 70.91 & 0.98 & - & - & - \\
\hline FeAl-PILC & - & - & - & 0.099 & 378.79 & 0.99 \\
\hline
\end{tabular}

The residual concentrations at equilibrium of the MO, diluted urban wastewater treated by both $\mathrm{Na}^{+}$-montmorillonite and FeAl-PILC clay, were shown in Figure 4. It was found that the concentration of M.O decreased with an in- 


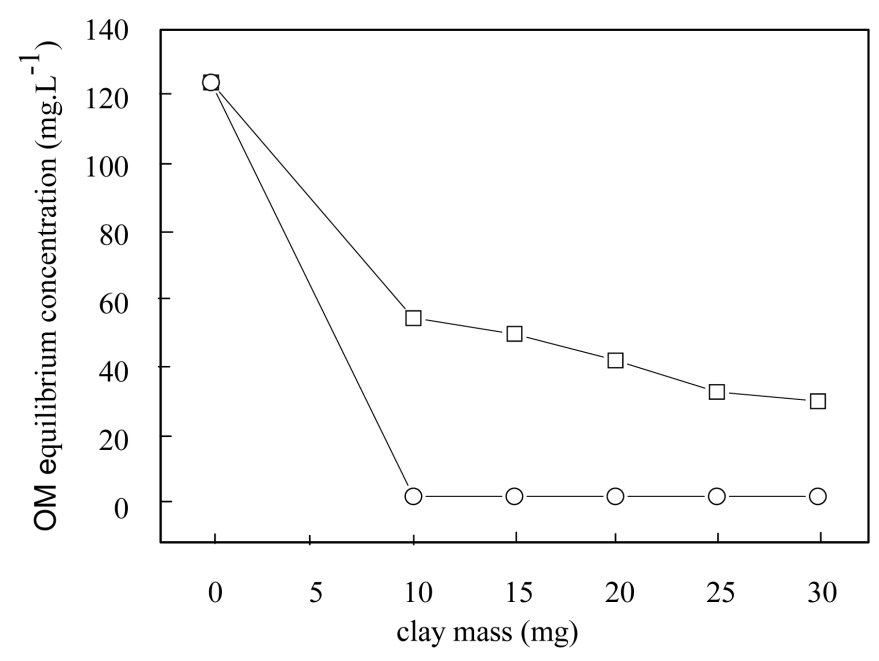

Figure 4. Variation equilibrium concentration of OM: $\square$ purified bentonite; O FeAl-PILC.

crease in adsorbent mass. This was expected, for an adsorbent mass of $25 \mathrm{mg}$ for puri.bent and $10 \mathrm{mg}$ for FeAl-PILC clay by $15.01 \mathrm{~cm}^{3}$ of raw urban wastewater were sufficient to remove most of the OM from the raw urban wastewater, fixation rates of MO per unit mass of the adsorbent were shown in Table 5, FeAl-PILC clay showed an excellent potential for the removal of organic matter from wastewater with a rate $97 \%$.

Organic matters adsorption data were very well described by the Freundlich equation for puri.bent (Figure 5), however, the adsorption data of the FeAl-PILC was good fitted to the Elovitch equation (Figure 6).

The value of the Freundlich parameter $k_{F}$ and $n$ were 70.91 and 1.09 respectively, the magnitudes of $k_{F}$ and $n$ showed easy sorption of OM from the diluted wastewater and indicate favourable adsorption. The intercept $k_{F}$ value was an indication of the adsorption capacity of the adsorbent, which reflects the number of sorptive sites. The slope $1 / n$ indicates the effect of concentration on the adsorption capacity and represents adsorption intensity, parameter characterizing energetic heterogeneity of the adsorption surface, i.e., surface with non-energetically equivalent sites. As seen from Table 4, $n$ value $>1$ indicated favourable adsorption can be explained by assumption of multilayer adsorption phenomena, energy of digital distribution of sorptive sites $Q_{0}$ equal 2669.9 $\mathrm{J} \cdot \mathrm{g}^{-1}$, Equation (1) and Equation (2). This value corresponding to the conditions the residual concentration at equilibrium of MO was $34 \mathrm{mg} \cdot \mathrm{L}^{-1}$ or $90 \mathrm{mg}(x)$ of organic matter adsorbed on $25 \mathrm{mg}(\mathrm{m})$ of clay (Figure 4, Figure 5). Freundlich isotherm fitted well with the correlation coefficient $\left(R^{2}\right)$ of 0.98 .

The adsorption data for FeAl-PILC clay were also evaluated according to the Elovitch isotherm Equation (2), this model also assumes a multilayer behavior for the adsorption of OM onto FeAl-PILC, with recovery rate adsorption sites 0.91 and fixation rate of OM equal $97 \%$ (Table 5). The value of Elovitch constant $\left(K_{E}=0.099 \mathrm{~L} / \mathrm{g}\right.$ ) and the maximum adsorption capacity $\left(q_{m}=378.79 \mathrm{mg} \cdot \mathrm{MO} \cdot \mathrm{g}^{-1}\right)$ were listed in Table 4 and the plot of this isotherm is shown in Figure 6. The correlation coefficient $\left(R^{2}\right)$ of 0.99 obtained showed that adsorption of OM also followed Elovitch isotherm.

The Freundlich isotherm was more widely used but provides no information on the maximum adsorption capacity $\left(q_{m}\right)$ for puri.bent but a polynomial regression of order 2 (Figure 7) indicates that was, $571 \mathrm{mg} \cdot \mathrm{MO} \cdot \mathrm{g}^{-1}$ and $1120 \mathrm{mg} \cdot \mathrm{MO} \cdot \mathrm{g}^{-1}$ for FeAl-PILC. Therefore the adsorptions of organic matters were on monolayer for puri.bent and, on multilayer for FeAl-PILC.

\section{Conclusions}

In this work, hydroxy-Fe and hydroxy-Al, mixed have been used as pillaring species to modify the Algerian natural bentonite $\left(\mathrm{Na}^{+}\right.$-montmorillonite, C E C $\left.=91 \mathrm{meq} / 100 \mathrm{~g}\right)$ for adsorption of organic matters from the effluent from wastewater treatment plant (STEP) of Sidi Bel-Abbes city. The study results demonstrated that increase in basal spacing $\left(\mathrm{d}_{001}\right)$, and specific surface area occurs in the presence of the mixed hydroxy-FeAl $(\mathrm{OH} / \mathrm{M}=2.5)$, as mentioned in the literature. Experimental results were in good agreement with Freundlich and 
Table 5. Fixation rates of OM and mass of sorbent per 1liter for urban wastewater.

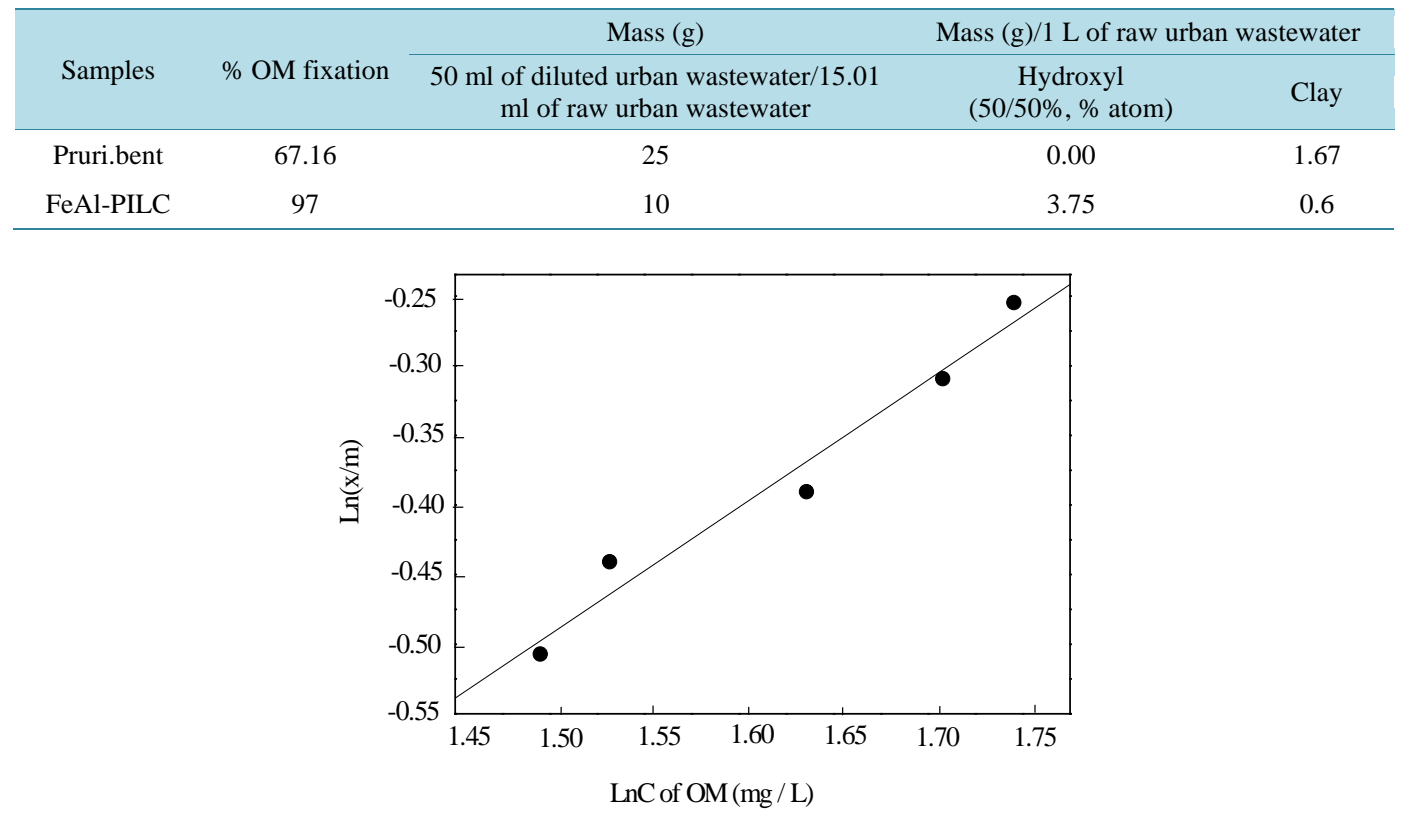

Figure 5. Linear plot of Freundlich isotherm for purified bentonite.

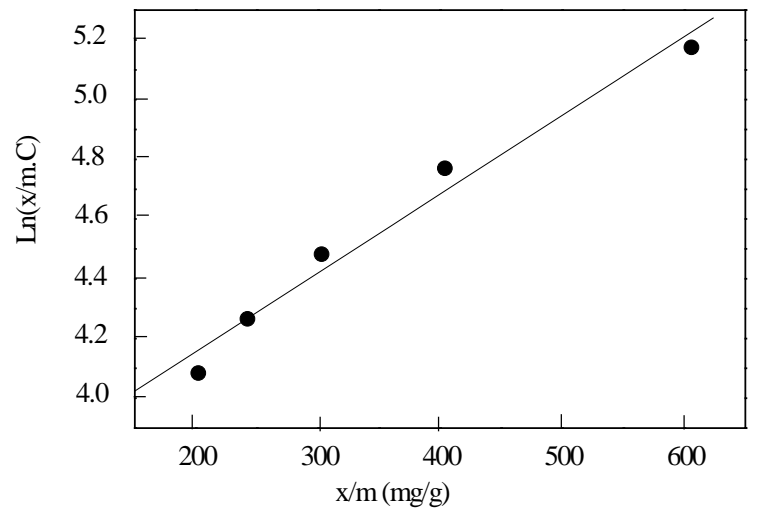

Figure 6. Linear plot of Elovitch isotherm for FeAl-PILC.

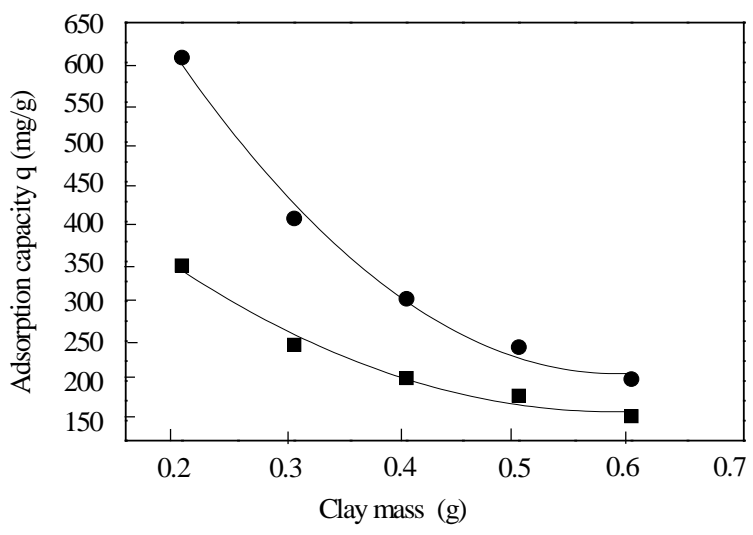

Figure 7. Adsorption capacity $(q)$ for: $\mathbf{~ p u r i f i e d ~ b e n t o n i t e ; ~}$ - FeAl-PILC. 
Elovitch isotherm models, and had showed a good fitting to the experimental data. Adsorption of OM on puri.bent obeys Freundlich model with good correlation.

$\left(R^{2} \approx 0.98\right)$ and the value of Freundlich parameter, $n=1.09$ confirmed that the adsorption was favourable. But the adsorption on FeAl-PILC was fitted to the Elovitch equation, with $R^{2}$ value $\approx 0.99$. The adsorptions of organic matters were on monolayer for puri.bent and, on multilayer for FeAl-PILC. The maximum adsorption capacity $\left(q_{m}\right)$ was determined by the polynomial regression of order 2 of the capacity adsorption $(q)$ as a function of the mass of the adsorbent, at 571.6 for puri.bent and $1120.69 \mathrm{mg} \cdot \mathrm{g}^{-1}$ for FeAl-PLC. It was evident that this last sample due to the fixation rate of OM equals $97 \%$.

Finally as a result this bentonite modified clay, by the mixed hydroxy-iron and aluminum, was the best performance which could be successfully applied in the urban wastewater treatments.

\section{References}

[1] Kettab, A. (2001) Les ressources en eau en Algérie: Stratégies, enjeux et vision. Desalination, 136, 25-33. http://dx.doi.org/10.1016/S0011-9164(01)00161-8

[2] Mecabih, Z., Kacimi, S. and Bouchikhi, B. (2006) Adsorption des matières organiques des eaux uses urbaines sur la bentonite modifiée par Fe (III), Al (III) et Cu (II). Revue des sciences de l'eau, 19, 23-31.

[3] Boufatit, M., Ait-Amar, H. and McWhinnie, W.R. (2004) Development of an Algerian Material Montmorillonite Clay for the Specific Sorption of Named Environmental Contaminants. Proceedings of the 4th International Congress of Aegean Analytical Chemistry, Turkey, 29 September-3 October 2004, Book 182.

[4] Amuda, O.S., Giwa, A.A. and Bello, I.A. (2007) Removal of Heavy Metal from Industrial Wastewater Using Modified Activated Coconut Shell Carbon. Biochemical Engineering Journal, 36, 174-181. http://dx.doi.org/10.1016/j.bej.2007.02.013

[5] Ngah, W.S.W. and Hanafiah, M.A.K.M. (2008) Removal of Heavy Metal Ions from Wastewater by Chemically Modified Plant Wastes as Adsorbents: A Review. Bioresource Technology, 99, 3935-3948. http://dx.doi.org/10.1016/j.biortech.2007.06.011

[6] Barrault, J., Abdellaoui, M., Bouchoule, C., Majesté, A., Tatibouët, J.M., Louloudi, A., Papayannakos., N. and Gangas, N.H. (2000) Catalytic Wet Peroxide Oxidation over Mixed Al-Fe Pillared Clays. Letter Applied Catalysis B: Environmental, 27, 225-230. http://dx.doi.org/10.1016/S0926-3373(00)00170-3

[7] Carriazo, J.G., Guelou, E., Barrault, J., Tatibouët, J.M. and Moreno, S. (2003) Catalytic Wet Peroxide Oxidation of Phenol over Al-Cu or Al-Fe Modified. Applied Clay Science, 22, 303-308. http://dx.doi.org/10.1016/S0169-1317(03)00124-8

[8] Jiang, J.Q., Cooper, C. and Ouki, S. (2002) Comparison of Modified Montmorillonite Adsorbents. Part I: Preparation, Characterization and Phenol Adsorption. Chemosphere, 47, 711-716. http://dx.doi.org/10.1016/S0045-6535(02)00011-5

[9] Sugunan, S. and Rahna, K.S. (2002) Surface Acidity and Catalytic Activity of Mixed Fe-AI and Cr-AI Pillared Montmorillonites. Indian Journal of Chemistry, 41, 1355-1362.

[10] Zeng, X.Q. and Liu, W.P. (2004) Preparation and Characterization of Mixed Hydroxyl-Fe-Al Pillared Montmorillonite. Journal of Environmental Sciences, 16, 117-119.

[11] Cooper, C. and Jiang, J.Q. (2002) Preliminary Evaluation of Polymeric Fe and Al Modified Clays as Adsorbents for Heavy Metal Removal in Water Treatment. Journal of Chemical Technology and Biotechnology, 77, 546-551. http://dx.doi.org/10.1002/jctb.614

[12] Al-Jlil, S.A. and Alharbi, O.A. (2010) Comparative Study on the Use of Reverse Osmosis and Adsorption Process for Heavy Metals Removal from Wastewater in Saudi Arabia. Research Journal of Environmental Sciences, 4, 400-406. http://dx.doi.org/10.3923/rjes.2010.400.406

[13] Allen, S.J. and Koumanova, B. (2005) Decolourisation of Water/Wastewater Using Adsorption (Review). Journal of the University of Chemical Technology and Metallurgy, 3, 175-192.

[14] Cool, P. and Vansant, E.F. (1998) Pillared Clays: Preparation, Characterization and Applications. Molecular Sieves, 1, 265-288. http://dx.doi.org/10.1007/3-540-69615-6_9

[15] Mandalia, T., Crespin, D. and Messad, D. (1998) Large Interlayer Repeat Distances Observed for Montmorillonite by Mixed Al-Fe Pillaring Solution. Chemical Communications, 19, 2110-2112.

[16] Salerno, P., Asenjo, M.B. and Mandioz, J. (2001) Influence of Preparation Method on Thermal Stability and Acidity of Al-PILCs. Thermochimica Acta, 379, 101-109. http://dx.doi.org/10.1016/S0040-6031(01)00608-6

[17] Besson, G., Drit, V.A., Daynayak, L.G. and Smoliar, B.B. (1987) Analysis of Cation Distribution in Dioctahedral Micaceous Minerals on the Basis of IR Spectroscopy Data. Clay Minerals, 22, 465-478.

http://dx.doi.org/10.1180/claymin.1987.022.4.10 
Scientific Research Publishing (SCIRP) is one of the largest Open Access journal publishers. It is currently publishing more than 200 open access, online, peer-reviewed journals covering a wide range of academic disciplines. SCIRP serves the worldwide academic communities and contributes to the progress and application of science with its publication.

Other selected journals from SCIRP are listed as below. Submit your manuscript to us via either submit@scirp.org or Online Submission Portal.
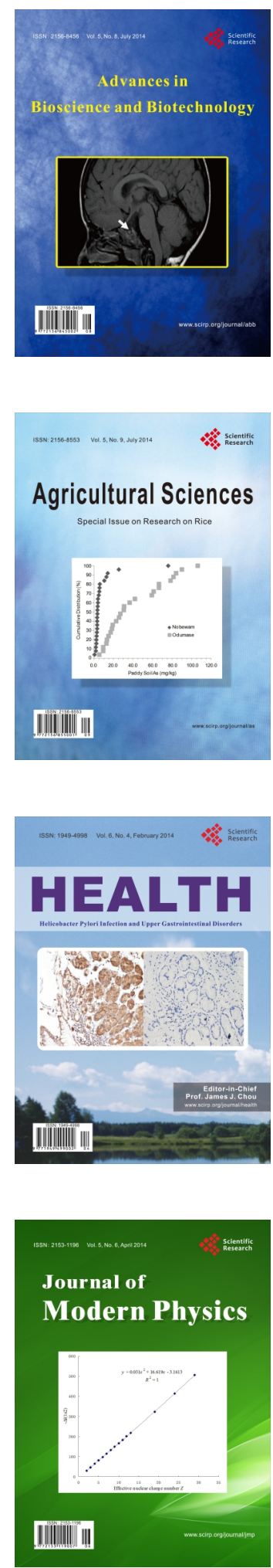
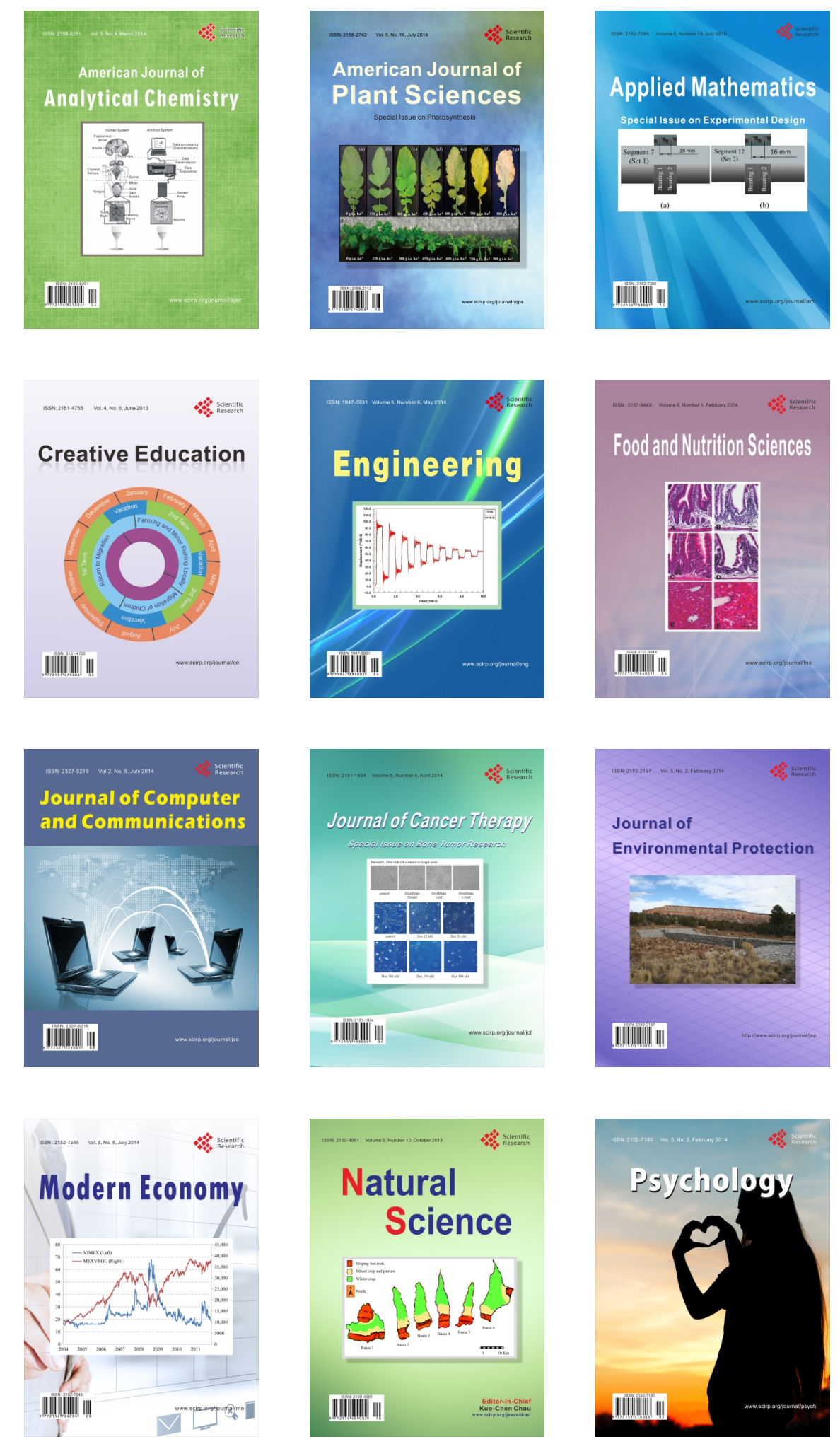